\title{
Palynological assessment of the atmosphere in the city of Cherepovets
}

\author{
Alexandra Kamygina ${ }^{1, *}$, Maria Smirnova $^{1}$, Natalia Afanasyeva ${ }^{2}$, Nadezhda Poddubnaya $^{1}$ \\ ${ }^{1}$ Cherepovets State University, Department of biology, Ecological-research laboratory, 160600 \\ Lunacharski Prospect, Cherepovets, Russia \\ ${ }^{2}$ Lomonosov Moscow State University, Faculty of Biology, Department of Plant Physiology, 119991 \\ Leninskie Gory, Moscow, Russia
}

\begin{abstract}
The article presents the results of the study of aeropalinological spectra of the city of Cherepovets $\left(59^{\circ} 07^{\prime} 59^{\prime \prime} \mathrm{N}, 37^{\circ} 53^{\prime} 59^{\prime \prime} \mathrm{E}\right)$, carried out during the growing season 2014-2015. The method of gravimetric sampling was used (Durham's pollen trap). Data was obtained on 22 taxa and the dynamics of dusting of various palynomorphs; the dominant taxa of palinospectrum were identified, as well as non-pollen palynomorphs in the air. It is shown that Betula pollen grains prevail in the atmosphere of the city. The pollen of woody plants occupies $80 \%$ of the total spectrum, and the pollen of herbaceous plants $-20 \%$. Seasonal highs are recorded twice: in May and in late June - early July. This information must be taken into account when accompanying patients with hay fever.
\end{abstract}

\section{Introduction}

In the atmosphere surrounding a person, a large number of particles of various origins are constantly circulating, which form air plankton. Among them, pollen and plant fragments play a special role. Spores of various plants, fungi, bacteria, etc. are also important components of atmospheric aerosols. Many of them, primarily pollen grains of plants, have long been known as an etiological factor for hay fever - a classic allergic disease associated with intolerance to plant pollen antigens by humans and can significantly affect the quality of life $[1,2,3]$.

Allergy is now a major public health problem. In Russia, according to the research results of the State Research Center "Institute of Immunology" of the Federal Medical and Biological Agency of Russia, various forms of allergic diseases suffer from $17.5 \%$ to $30 \%$ of the population. Seasonality is a hallmark of pollen allergy. The severity of symptoms in patients with hay fever is directly proportional to the concentration of allergens in the atmosphere [4]. As a result, the number of aeropalinological studies is steadily increasing in many regions of Russia.

The pollen of many plants in itself is a strong allergen, but in many industrial regions the problem can be aggravated, as the likelihood increases that under the influence of various environmental factors pollen grains will begin to deform, and their allergenic

\footnotetext{
* Corresponding author: camygina@yandex.ru
} 
properties significantly change and intensify [5-9]. In general, the amount of pollen in the air is determined by many factors, and therefore long-term observations should be carried out, while data analysis should include various aspects [4].

In the prevention and treatment of allergic diseases, dust calendars prepared in a specific region are a valuable source of information. Due to the diversity of vegetation and climatic parameters of the habitat, such calendars are of particular importance only for a specific area. The dynamics and duration of dusting, the total amount of pollen grains strongly depend on the geographic location of the territory.

The aim of the work was to obtain an aeropalinological calendar for such a large industrial center of the Vologda Oblast as Cherepovets, in the interest of developing recommendations for reducing the level of pollinosis in the region.

\section{Materials and Methods}

The studies were carried out in the Cherepovets city $\left(59^{\circ} 07^{\prime} 59^{\prime \prime} \mathrm{N}, 37^{\circ} 53^{\prime} 59^{\prime \prime} \mathrm{E}, 130\right.$ $140 \mathrm{~m}$ above sea level) in the Vologda region, located in the zone of the temperate continental climate of the eastern European taiga. The basis of the vegetation cover of the region is formed by forests: spruce and pine forests, and in the southern part of the region the participation of woody broad-leaved plant species is noticeable.

The study was carried out during the growing season from April to September 20142015. To establish the taxonomic composition of pollen and its average daily concentration, the gravimetric Durham trap was used [10], which was installed on an open roof space in the center of the city at a height of about $15 \mathrm{~m}$. The counting and study of pollen grains was carried out using a light microscope with a magnification of $\times 640$ on an area of $1 \mathrm{~cm}^{2}$ of a glass slide (the number of pollen grains and specimens of other occurring particles was counted).

The development of dusting calendars was carried out according to the recommendations for European aeropalinological monitoring stations. According to international rules, fifteen types of pollen dominating in the pollen spectra and possessing strong allergenic properties were selected for the dusting calendar $[5,10]$.

The calendar was built in the form of a table, in which the cell represented a decade. For each decade, the total content of pollen grains of woody and herbaceous plants was determined, and then all cells were colored in accordance with the average daily level of pollen or spores for a decade: low, medium, high, and very high [11]. Spores of fungi and Lycopodium and other non-pollen palynomorphs were analyzed in the total volume of material and separate calendars were built for them.

Statistical analysis was performed using Spearman's correlation test using StatSoft Statistica 10 and Microsoft Excel 2016; significance was determined at $p<0.05$.

\section{Results and discussion}

A study of the qualitative and quantitative characteristics of pollen rain in the atmosphere of Cherepovets in 2014 showed 18 types of pollen (Acer, Alnus, Betula, Fraxinus, Picea, Pinus, Populus, Rosaceae, Salix, Tilia, Artemisia, Asteraceae, Chenopodiaceae, Plantago, Poaceae, Rumex, Umbelliferae, Urtica). Also, single spores of plants from the genus Lycopodium were found (Fig. 1). 


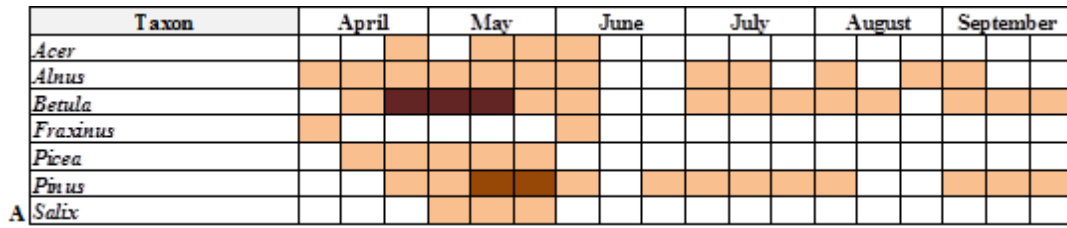
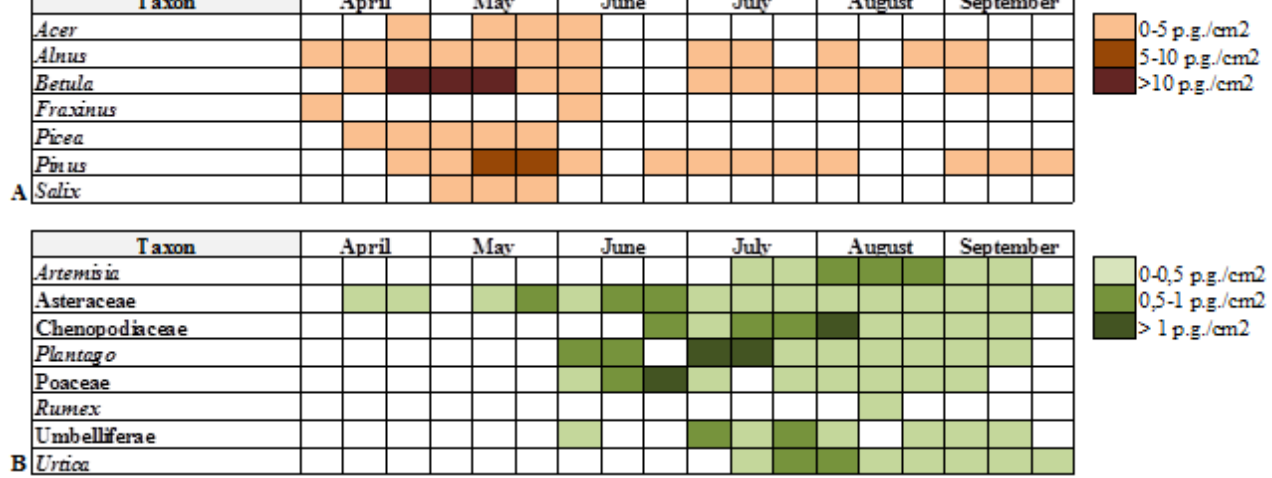

Fig. 1 Dusting calendar of A - woody and shrub plants and B - herbaceous plants in Cherepovets in 2014

The dominants were 7 taxa of woody plants (Acer, Alnus, Betula, Fraxinus, Picea, Pinus, Salix), the pollen of which constituted $75 \%$ of the total number of pollen grains found and 8 taxa of herbaceous plants (Artemisia, Asteraceae, Chenopodiaceae, Plantago, Poaceae, Rumex, Umbelliferae, Urtica), the pollen of which was $25 \%$. Aeropalinological observations in Cherepovets continued in 2015 and showed that the spectrum contains 21 types of pollen (Acer, Alnus, Betula, Fraxinus, Picea, Pinus, Populus, Quercus, Rosaceae, Salix, Tilia, Ulmus, Artemisia, Asteraceae, Chenopodiaceae, Plantago, Poaceae, Rumex, Taraxacum, Umbelliferae, Urtica). Also, single spores of plants from the genus Lycopodium were found (Fig. 2).

\begin{tabular}{|l|l|l|l|l|l|l|l|l|l|l|l|l|l|l|l|}
\hline \multicolumn{1}{|c|}{ Taxon } & \multicolumn{2}{|c|}{ April } & \multicolumn{3}{c|}{ May } & \multicolumn{3}{c|}{ June } & \multicolumn{3}{c|}{ Juk } & \multicolumn{2}{c|}{ August } \\
\hline Acer & & & & & & & \\
\hline Alnus & & & & & & & & & & & & & & & \\
\hline Betula & & & & & & & & & & & & & & & \\
\hline Picea & & & & & & & & & & & & & & & \\
\hline Pinus & & & & & & & & & & & & & & & \\
\hline Populus & & & & & & & & & & & & & & & \\
\hline Ouercus & & & & & & & & & & & & & & & \\
\hline
\end{tabular}

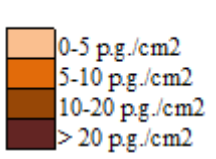

\begin{tabular}{|c|c|c|c|c|c|c|}
\hline Taxon & April & May & June & Juk & August & \\
\hline Artemisia & & & & & & $0-0,5$ p.g. $/ \mathrm{cm} 2$ \\
\hline Asteraceae & & & & & & $0,5-1$ p.g. $/ \mathrm{cm}^{2}$ \\
\hline Chenopodiaceae & & & & & & $1-2 \mathrm{pg} / \mathrm{cm} 2$ \\
\hline Plantago & & & & & & $>2 \mathrm{pg} / \mathrm{cm} 2$ \\
\hline Poaceae & & & & & & \\
\hline Rumex & & & & & & \\
\hline Umbelliferae & & & & & & \\
\hline Urtica & & & & & & \\
\hline
\end{tabular}

Fig. 2 Dusting calendar of A - woody and shrub plants and B - herbaceous plants in Cherepovets in 2015

The dominants were 8 taxa of woody plants (Acer, Alnus, Betula, Picea, Pinus, Populus, Quercus, Salix), whose pollen accounted for almost $85 \%$ of the total number of pollen grains and 8 taxa of herbaceous plants (Artemisia, Asteraceae, Chenopodiaceae, Plantago, Poaceae, Rumex, Umbelliferae, Urtica), the pollen of which was $15 \%$.

Two dusting peaks are well traced in the calendars: spring (last ten days of April May), caused by the flowering of anemophilous woody and shrub plants, and summer (late June - early and mid-July), caused by the flowering of herbaceous plants. It can be concluded that Betula pollen is the main component of the aeropalinological spectrum of 
the atmosphere of Cherepovets (almost $38 \%$ of the annual total of all pollen grains). Pinus pollen is contained less $(21 \%)$ in the city atmosphere.

The content of other taxa in the palynospectrum is insignificant individually. The prevalence of pollen grains of woody and shrubby plants in the total spectrum is associated mainly with the flora of the region and the spectrum of plants that are used in landscaping the city.

Most of the pollen we found is allergenic (slightly less than $88 \%$ of the total number of grains): Alnus, Betula, Fraxinus, Picea, Pinus, Quercus, Artemisia, Chenopodiaceae, Plantago, Poaceae, Rumex, Urtica. Artemisia is considered the most active allergen among all noted taxa. In addition to pollen grains of plants, we also found non-pollen palynomorphs: remnants of plant tissues, spores of fungi and Lycopodium, arthropods and their parts (Fig. 3, 4).

\begin{tabular}{|c|c|c|c|c|c|c|c|}
\hline Non-pollen palsnomorphs & April & Mav & June & Julv & August & September & \\
\hline Lycopodium & & & & & & & $0-0.05$ p.p. $/ \mathrm{cm}^{2}$ \\
\hline Phnt residues & & & & & & & $0.05-0.1$ p.p. $/ \mathrm{cm} 2$ \\
\hline F ungal spores & & & & & & & $>0,1$ p.p. $/ \mathrm{cm} 2$ \\
\hline Arthropods and their parts & & & & & & & \\
\hline
\end{tabular}

Fig.3 Calendar of occurrence of non-pollen palynomorphs in the air of Cherepovets in 2014

\begin{tabular}{|c|c|c|c|c|c|c|}
\hline Non-pollen pahnomorphs & April & May & June & Juk & August & \\
\hline$L_{\text {1copodium }}$ & & & & & & $0-0,05$ p.p. $/ \mathrm{cm} 2$ \\
\hline Plant residues & & & & & & $0,05-0,1$ p.p. $/ \mathrm{cm} 2$ \\
\hline Fungal spores & & & & & & $>0,1$ p.p. $/ \mathrm{cm} 2$ \\
\hline Arthropods and their parts & & & & & & \\
\hline
\end{tabular}

Fig.4 Calendar of occurrence of non-pollen palynomorphs in the air of Cherepovets in 2015

The 2014 calendar shows that their role in the composition of air plankton begins to increase from the second decade of May and reaches its peak by the end of summer. In 2015, their occurrence is fairly uniform throughout the season, but a gap was observed in the first ten days of May. In the autumn spectra, the participation of non-pollen palynomorphs also remains noticeable. In general, non-pollen palynomorphs accounted for only $1.5 \%$ of the total spectrum.

In his studies, Kruczek [4] showed that the most common cause of allergic disease symptoms is the pollen of anemophilic woody plants, especially species that bloom before leaf development, which facilitates the spread of pollen grains. According to Severova [12], Betula pollen is an important arboreal taxon and one of the main components of the aeropalinological spectrum of central Russia, as a result of which it was included in the aeropalinological observation program. Birches produce a large number of small light pollen grains with a smooth surface, which can be transported hundreds or even thousands of kilometers by air masses [7, 8]. As our research has shown, for the Vologda Oblast, birches is also the main woody dominant of the spring period and further its pollen present in the spectrum throughout the entire dusting season. This may be due to the secondary uplift of pollen from the substrate, which is probably typical of species with high pollen productivity.

The dynamics and duration of dusting, the total amount of pollen grains, strongly depend on the geographic location. Studies of the distribution of Betula pollen in the air make it possible to determine the differences in the intensity and timing of pollination, caused, in particular, by the influence of climate change and air pollution on plants [7,8].

Pollen allergens from the genus Artemisia are also an important cause of hay fever in Europe. Our study revealed a noticeable presence of Artemisia pollen in the air plankton in Cherepovets in the last decades of summer. It should be noted that although Artemisia species are anemophilic plants, their pollen grains are not as well adapted for wind transport as other lighter and smaller ones (for example, Betula) [13, 14]. 
The results on the daily distribution of the seasonal amount of pollen grains in many countries proved a wide variety of models in anemophilous plants [4]. In general, the amount of pollen in the air is determined by many factors, and therefore long-term observations should be made, while data analysis should include various aspects.

\section{Conclusion}

Thus, according to the results of an aeropalinological study in the palynospectrum in Cherepovets in 2014-2015 22 taxa were identified. The greatest role in the spectrum is played by the pollen of anemophilous woody and shrub plants, among which Betula is the absolute dominant, the pollen of which is most dangerous in May. Also at the end of July and August, the peak of dusting of Artemisia, one of the most dangerous allergens in the North-West of European Russia, was noted. It can be concluded that it is advisable for the Cherepovets population to use personal protective measures during these periods.

\section{References}

1. K. Piotrowska-Weryszko, E. Weryszko-Chmielewska, Acta Agrobotanica, 68(4), 333341 (2015)

2. Yu. Posevina, E. Severova, Bulletin of the Moscow Society of Naturalists. Biological department, 1222 (4), 102-108 (2017)

3. K. Malygina, N. Minaeva, I. Koryukina, Perm medical journal. 5, 5-10 (2010)

4. A. Kruczek, M. Puc, A. Stacewicz, T. Wolski, Acta Agrobotanica, 68(4), 325-331 (2015)

5. Aeropalinological monitoring of allergenic plants in Barnaul: monograph (Inst. and eco. problems of the SB RAS, 2013) (in Russian)

6. C. Barck, T. Sandström, J. Lundahl, Respiratory Medicine, 96, 907-917 (2002)

7. L. Hajkova, V. Kožnarova, M. Možny, L. Bartošova, Acta Agrobotanica, 68(4), 285 $302(2015)$

8. M. Puc, T. Wolski, I. C. Camacho, Acta Agrobotanica, 68(4), 303-313 (2015)

9. O. Dzyuba, Neftegazovaya Geologiya, Theory and practice, 12 (1), 18 (2006)

10. Principles and methods of aeropalinological studies (Medicine, 1999) (in Russian)

11. Methods of aerobiological studies of plant pollen and fungal spores for compiling dusting calendars (Republican Scientific and Practical Center for Hygiene, 2005) (in Russian)

12. E. Severova, Bulletin of the Moscow Society of Naturalists. Biological department, 109 (1), 53-55 (2004)

13. Ł. Grewling, I. Kasprzyk, K. Borycka, Acta Agrobotanica, 68(4), 399-404 (2015)

14. M. Malkiewicz, K. Klaczak, A. Drzeniecka-Osiadacz, J. Krynicka, K. Migała, Aerobiologia, 30 (1), 13-23 (2014) 